\title{
Reactions of a calving glacier to large changes in water level
}

\author{
TRON LAUMANN AND BJøRN WOLD \\ Norwegian Water Resources and Energy Administration, P.O.Box 5091, Maj., N-0301 Oslo 3, Norway
}

\begin{abstract}
Austdalsvatn in western Norway was regulated in 1988 as a reservoir for a hydropower development. From a pre-1988 water level of $1157 \mathrm{~m}$ a.s.l. the new water level will vary more or less annually from 1170 to $1200 \mathrm{~m}$ a.s.l. The outlet glacier Austdalsbreen calves into this reservoir. About $1600 \mathrm{~m}$ up-valley from its terminus the glacier flows over a bedrock riegel that is, at its lowest point, $\sim 15 \mathrm{~m}$ above the projected maximum lake level of $1200 \mathrm{~m}$. As a result of the increase in water level, the surface velocity near the front has increased from about 0.07 to $0.13 \mathrm{~m} \mathrm{~d}^{-1}$.

Calculations suggest that the glacier terminus will retreat about $750 \mathrm{~m}$ in 50 years. The measured response of the glacier terminus for the first three years is in good agreement with the simulations.
\end{abstract}

\section{INTRODUCTION}

As part of the construction of the Jostedal hydropower station in western Norway, the water level in Austdalsvatn can vary between 1130 and $1200 \mathrm{~m}$ a.s.l. The previous normal water level in the lake was $1157 \mathrm{~m}$ a.s.l. An outlet glacier, Austdalsbreen, which drains the northern part of Jostedalsbreen, terminates in the reservoir (Fig. 1).

Radio-echo measurements (Sætrang, 1987) revealed

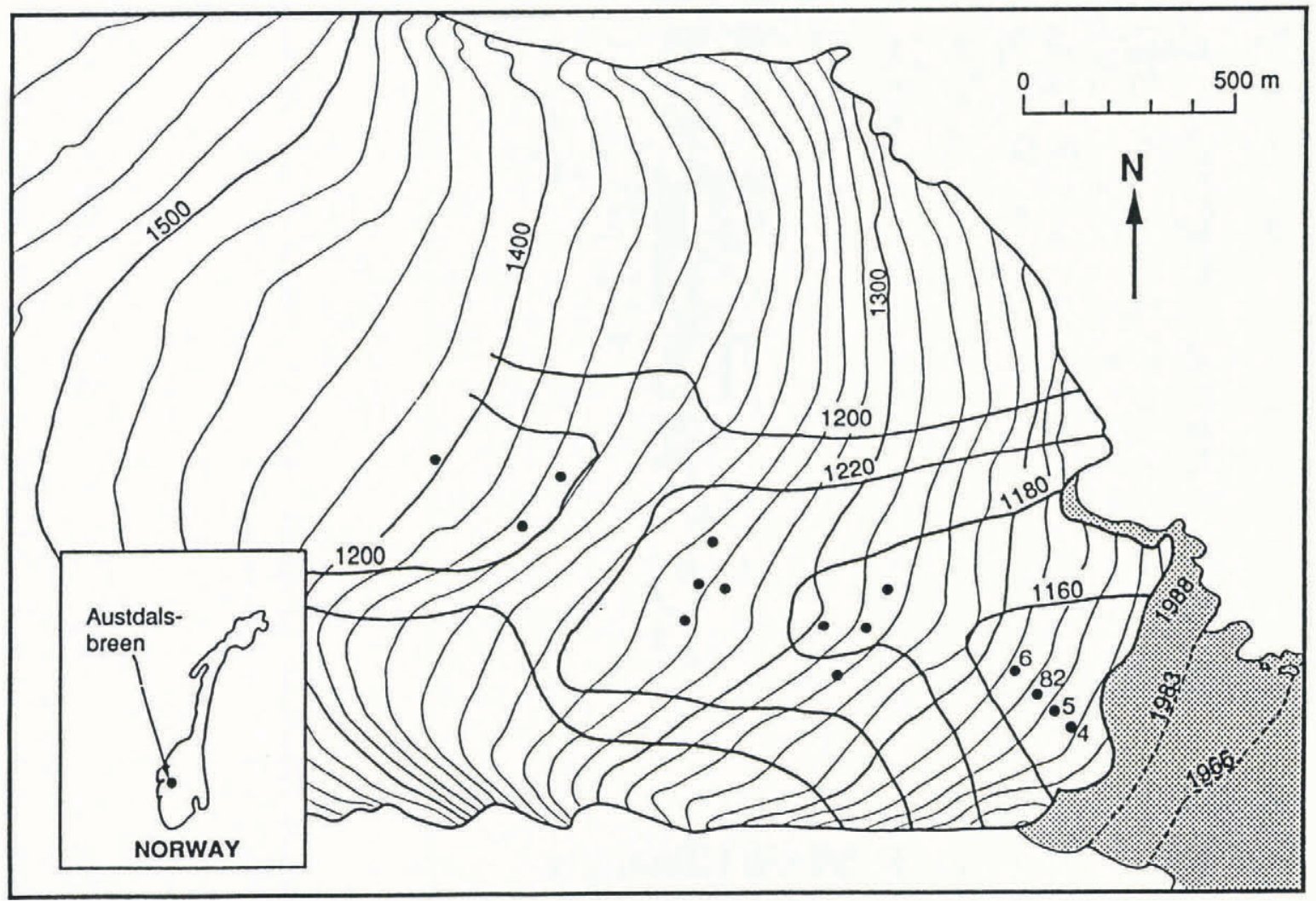

Fig. 1. Map of Austdalsbreen from 1988 showing positions of stakes with measured velocities, various front positions and the subglacial bed topography near the terminus. 


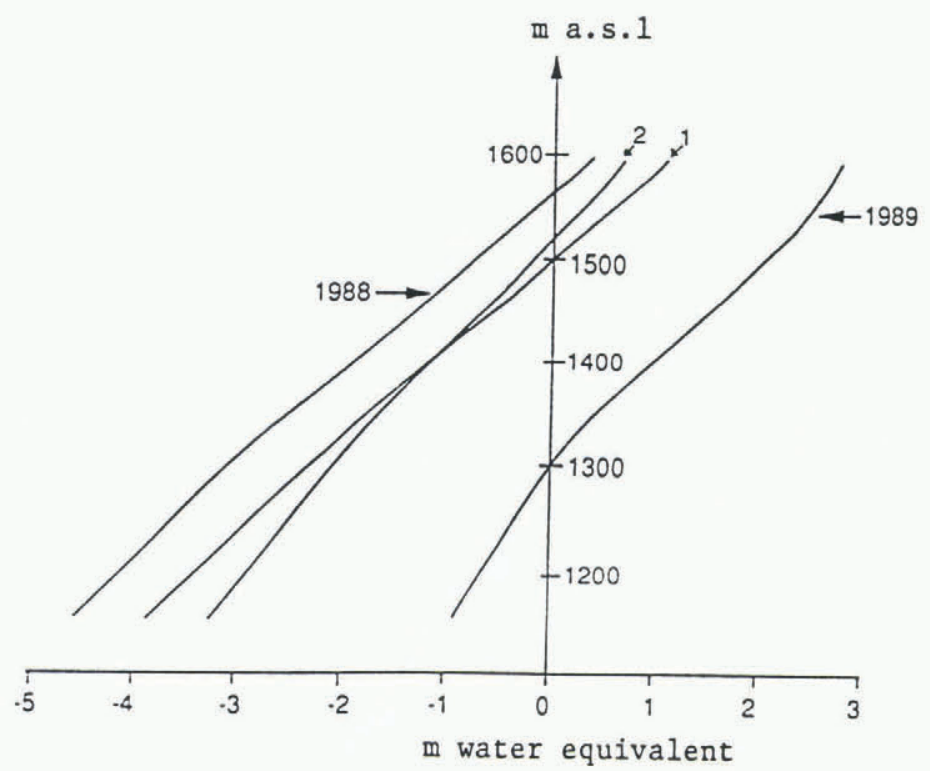

Fig. 2. Mass-balance curves for 1988 and 1989. See text for explanation of curves 1 and 2 .

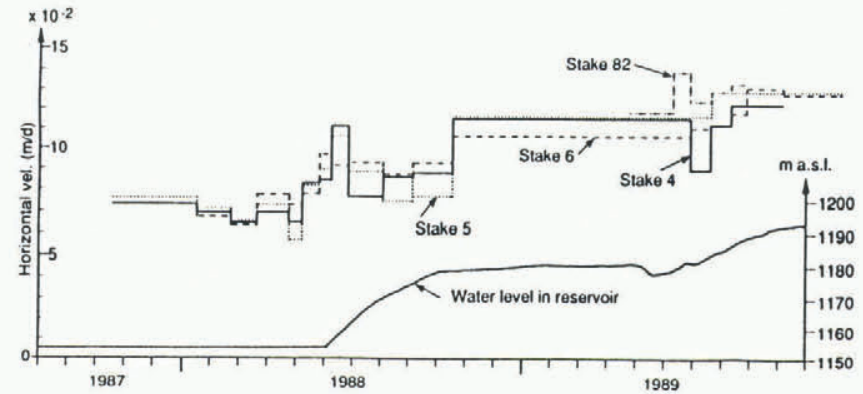

Fig. 3. Velocities for the lowest stakes (above), together with water-level changes in the reservoir (below). Stake positions are shown in Fig. 1. that $\sim 2 / 3$ of the glacier bed lay below the maximum water level. This prompted a comprehensive programme to evaluate the effect of water-level changes on the glacier. Mass balance, glacier velocity, changes in the glacier terminus, water pressures, and water-level changes were monitored, and theoretical simulations of the glacier response were made. This paper discusses the simulations and compares them with the actual glacier response since 1988.

\section{OBSERVATIONS}

\section{Mass balance}

Surface maps from 1966 and 1988 show that the surface near the front of Austdalsbreen has decreased in elevation by 30 to $40 \mathrm{~m}$ during this period. There was little or no change in the upper parts of the accumulation area. The total mass loss from the glacier is $\sim 111 \times 10^{6} \mathrm{~m}^{3}$ w.e. This includes $\sim 7 \times 10^{6} \mathrm{~m}^{3}$ due to retreat of the glacier front. With a glacier area of $10.2 \mathrm{~km}^{2}$, this mass loss corresponds to a mean net balance of $-0.47 \mathrm{~m}$ water equivalent per year.

Direct mass-balance measurements were obtained for 1988 and 1989. The net balances (Fig. 2) were extremely negative in $1988\left(b_{n}=-1.11 \mathrm{~m}\right.$ w.e. $)$ and extremely positive in $1989\left(b_{n}=+1.84 \mathrm{~m}\right.$ w.e.). Two possible mean net-balance curves for the period 1966-88 were constructed using the balance gradients for 1988 and 1989 (Fig.2, curves 1 and 2). These curves are derived from parallel displacement of the 1988 and 1989 curves respectively, and are positioned such that the overall net balance for the glacier corresonds to the calculated average net balance for the period 1966-1988, $-0.47 \mathrm{~m}$ w.e. From these curves it appears that the mean equilibrium line for the period has been between 1500 and $1520 \mathrm{~m}$ a.s.l.

\section{Measured velocities}

The velocities of several stakes were measured using an AGA geodimeter total station. Locations of the most important stakes are shown in Figure 1.

Figure 3 shows measured velocities for stakes near the glacier front from 1987 to 1989 . Errors are estimated to be $\sim \pm 0.01 \mathrm{~m} \mathrm{~d}^{-1}$ for measuring periods of 10 days, and proportionately less for longer periods. The velocity increased from $\sim 0.07 \mathrm{~m} \mathrm{~d}^{-1}$ in 1987 to $\sim 0.13 \mathrm{~m} \mathrm{~d}^{-1}$ in 1989. During the same period the water level in the reservoir was raised $46 \mathrm{~m}$. The velocity increase was only measurable within $500 \mathrm{~m}$ of the calving front.

\section{SLIDING}

It seems likely that the increase in velocity is due to increasing sliding as the water level in the lake increases. It was therefore necessary to establish a relationship between sliding and water level in order to calculate future front positions.

The most widely used relation for bed sliding, $u_{\mathrm{g}}$, is of the form:

$$
u_{\mathrm{g}}=\mathrm{k} \frac{\tau^{\mathrm{p}}}{N_{\mathrm{e}}^{\mathrm{q}}}
$$

where $\mathrm{p}, \mathrm{q}$ and $\mathrm{k}$ are constants, $\tau$ is basal shear stress and $\mathcal{N}_{\mathrm{e}}$ is the effective normal pressure.

By choosing $p=3$ and $q=1$ in Equation (1), Bindschadler (1983) obtained an approximate fit to data for Variegated Glacier with $\mathrm{k}=0.2 \mathrm{month}^{-1} \mathrm{bar}^{-2}$. With the same choice of $\mathrm{p}$ and $\mathrm{q}$, Budd and others (1979) obtained $\mathrm{k}$ values between 0.4 and $1.1 \mathrm{month}^{-1} \mathrm{bar}^{-2}$ in laboratory tests in which ice blocks were dragged over a rough granite surface. The variation in $k$ could be avoided by taking $\mathrm{q}=1.5$ with $\mathrm{k}=2.5 \mathrm{month}^{-1} \mathrm{bar}^{-1.5}$.

To evaluate the constants in Equation (1) for 
Austdalsbreen we first need to estimate $u_{\mathrm{g}}$ for various values of $\mathcal{N}_{\mathrm{e}}$ and $\tau$. To do this we first assume that internal ice deformation is constant in time. The sliding velocity is then calculated for various water levels from measured surface velocities. Three different models were used. The first was a two-dimensional finite-element model developed by Hooke and others (1979) and refined by Hanson (1985). The second was developed by van der Veen and Whillans (1989a, b) to calculate basal shear stress and sliding of large ice streams in Antarctica. Small changes were made to include the valley side friction on Austdalsbreen. The third was a finite difference model developed by Bindschadler (1982) for Variegated Glacier in Alaska, and adapted to Norwegian glaciers by Laumann (1987).

The glacier is temperate and flow-law parameters $\mathrm{n}=3$ and $\mathrm{A}=5.3 \times 10^{-15} \mathrm{~s}^{-1} \mathrm{kPa}^{-3}$ (Paterson, 1981, p. 39) were used for the calculations shown. Sensitivity tests indicated that other reasonable parameter values did not change the main result.

The results of the calculations of $u_{\mathrm{g}}$ for 1987-88 are plotted in Figure 4, together with surface velocities measured at that time, and longitudinal profiles of the surface and bed along the glacier centreline. The two riegels, or transverse bedrock ridges, have an obvious effect on the velocity. Outside the outer riegel (nearest to terminus) the $u_{\mathrm{g}}$ increases considerably, and for the outermost $500 \mathrm{~m}$ of the glacier nearly all the movement is due to sliding.

The basal shear stress is calculated using

$$
\tau=f \rho_{\mathrm{i}} g h_{\mathrm{i}} \sin \alpha
$$

where $\alpha$ is surface slope, $\rho_{\mathrm{i}}$ is ice density, $h_{\mathrm{i}}$ is ice thickness along the glacier centreline, $g$ is acceleration due to gravity and $f$ is a shape factor which takes into account friction from the valley sides (Paterson, 1981, p. 109).

The water level is included in the parameter $\mathcal{N}_{\mathrm{e}}$ which is equal to ice pressure minus water pressure. The water pressure is calculated as a buoyancy effect, assuming that water from the lake has free access to the bed. This assumption holds probably only near the terminus, especially if the glacier is heavily crevassed. The water from the lake will, however, certainly find its way to the

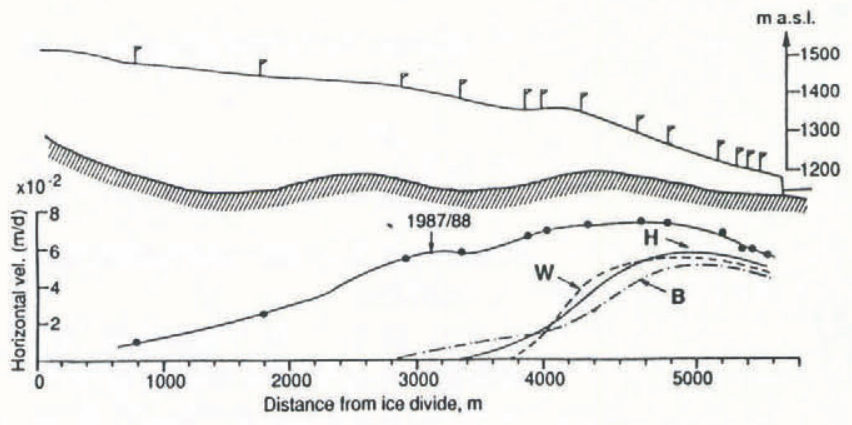

Fig. 4. Longitudinal profiles of the surface and bed along the glacier centreline, surface velocities measured in 198788 , and sliding velocities calculated using the various models. $H=$ Hanson's model; $W=$ Whillans' model; $B=$ Bindschadler's model.

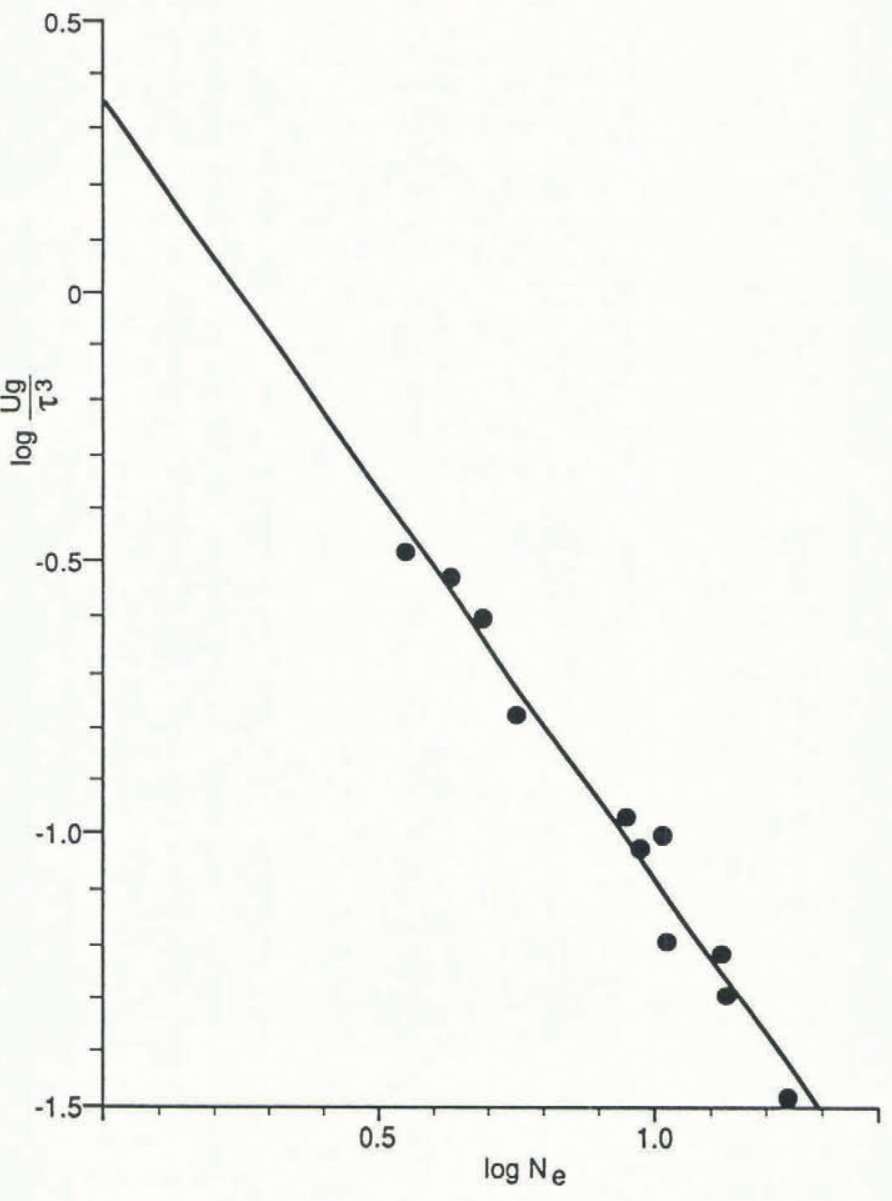

Fig. 5. Plot of $\left(u_{\mathrm{g}} / \tau^{3}\right)$ versus $\mathcal{N}_{\mathrm{e}}$.

bed and fill up the subglacial tunnels. The question is, then, how great an area those tunnels occupy. Is there only one tunnel or is the drainage system more like a linked-cavity system? Although somewhat dubious, our assumption that the water in the lake has free access to the bed would be most plausible if the drainage system were similar to a linked-cavity type of system. $\mathcal{N}_{\mathrm{e}}$ is calculated from

$$
N_{\mathrm{e}}=\rho_{\mathrm{i}} g h_{\mathrm{i}}-\rho_{\mathrm{w}} g h_{\mathrm{w}}
$$

where $\rho_{\mathrm{w}}$ is water density and $h_{\mathrm{w}}$ is the difference in elevation between the lake level and the average bed elevation in cross-sections spaced at intervals of $460 \mathrm{~m}$ along a flowline.

The constant $p$ in Equation (1) is set equal to 3, while $\mathrm{q}$ and $\mathrm{k}$ are adjusted to obtain agreement with measured velocities for various reservoir levels. They are found from the slope and intercept, respectively, a plot of $\log \left(u_{\mathrm{g}} / \tau^{3}\right)$ versus $\log \mathcal{N}_{e}$ (Fig. 5). The best-fit line yields $q=1.46$ and $k=2.23$. These values are very close to those of Budd and others (1979).

\section{HISTORIC GHANGES IN GLAGIER TERMINUS POSITION}

Figure 1 shows the glacier terminus as mapped from air photographs taken in 1966, 1983 and 1988. The retreat from 1966 to 1983 was $\sim 100 \mathrm{~m}$, or $\sim 6 \mathrm{~m} \mathrm{~s}^{-1}$. Using an estimated glacier movement of $25 \mathrm{~m} \mathrm{a}^{-1}$, as measured in $1986-87$, the calving speed must be $\sim 31 \mathrm{~m} \mathrm{a}^{-1}$. The water 
depth is 7 to $10 \mathrm{~m}$. The empirical relation found by Funk and Röthlisberger (1989) gives a calving speed of 15 to $30 \mathrm{ma}^{-1}$ for these depths, which is in reasonable agreement with that inferred from the retreat rate.

From 1983 to 1988 several calving bays were created. Calving rates vary considerably along the glacier terminus during this period, which makes the use of empirical average equations difficult. Generally the calving rate for this period has been slightly higher than calculated before the increase in water level, probably due mainly to the influence of changing water depth and of the subglacial and proglacial rivers flowing approximately parallel to the calving face.

\section{SIMULATIONS}

\section{Models and scenarios}

Calculations of possible changes in the terminus of Austdalsbreen have been made using a simple steadystate simulation and a dynamic model. The steady-state simulation is similar to the study made for a Swiss glacier

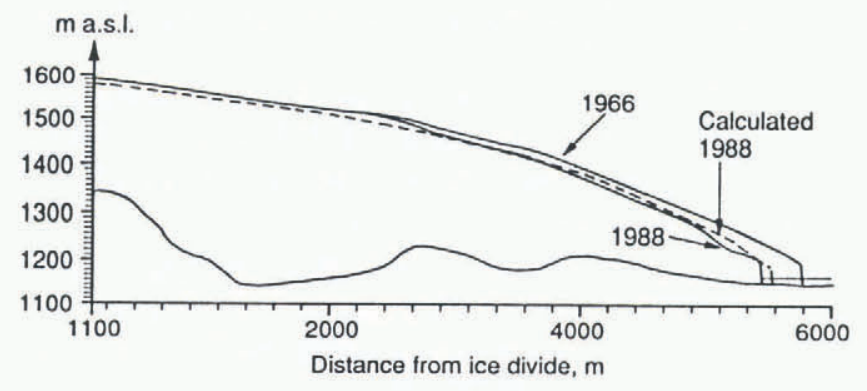

Fig. 6. Longitudinal profiles along the centreline. From maps (1966 and 1988) and calculated with the dynamic model for the 1988 situation.

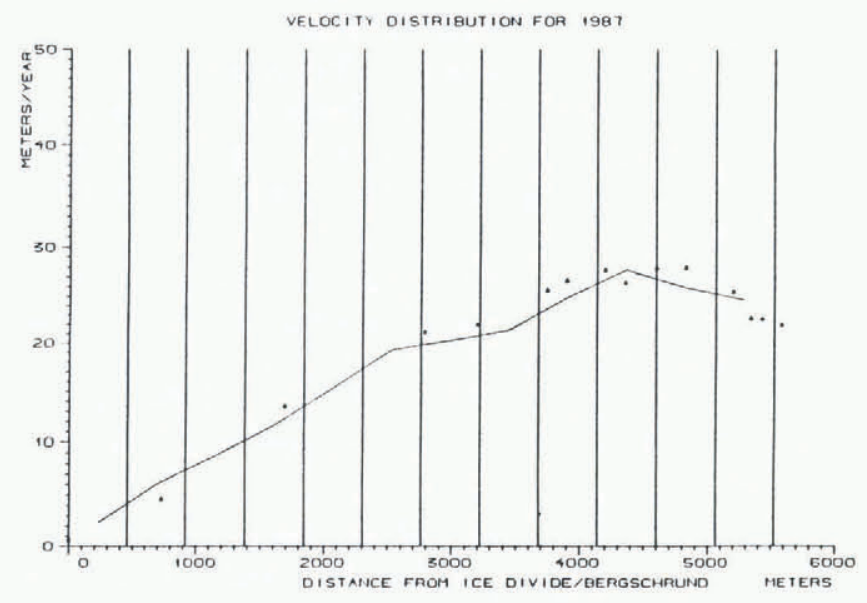

Fig. 7. Calculated (solid line) and measured (triangles) velocities along the centreline. Vertical lines are boundaries between the model sections. by Funk and Röthlisberger (1989), and results for Austdalsbreen have previously been published by Hooke and others (1989). The most important assumption in these calculations was that the surface profile is a steadystate profile, and that the mass balance will not change substantially. Other important factors not taken into account are calving, when the glacier terminus begins to float, increasing glacier movement due to reduced friction, and large variations in calving rate due to large water-level variations.

The dynamic model is developed for Variegated Glacier by Bindschadler (1982) and adapted to Norwegian glaciers by Laumann (1987). Sliding is calculated using Equation (1), and calving is calculated using Funk and Röthlisberger's (1989) empirical relationship which, as noted gives reasonable agreement for calving from 1966 to 1988 . The model is calibrated using surface profile changes between 1966 and 1988 (Fig. 6) and measured velocities from 1987 (Fig. 7).

Simulations are made for three climate scenarios: (1) Equilibrium net balance $\left(b_{n}=0\right),(2)$ net balance equal to the 1966-88 mean $\left(b_{n}=-0.47\right)$, and (3) a climate influenced by increasing greenhouse gases up to a doubling of $\mathrm{CO}_{2}$ by $2030 \mathrm{AD}$. The third scenario is based on that reported by a Norwegian expert team in a report to an Interdepartmental Group for Assessing Consequences of Climate Changes (Eliassen and others, unpublished; Sælthun and others, 1990). Scenarios are given for temperature and precipitation. The one considered to be most likely predicts an increase in temperature of 1.5 to $3.5^{\circ}$, and an increase in precipitation of 7 to $8 \%$.

For each scenario, simulations are made for two constant water levels (1157 and $1200 \mathrm{~m}$ a.s.l.), and for the normal expected yearly water-level variation between 1170 and $1200 \mathrm{~m}$ a.s.l. The highest level is in the autumn and the lowest level in spring.

\section{Results}

The results are shown in Fig. 8. The three uppermost curves give the position of the terminus without waterlevel changes. As expected, the changes in front position are small for $b_{n}=0$. For $b_{n}=-0.47$ a retreat of $200 m$ is predicted to occur within 50 years, and for the warmer

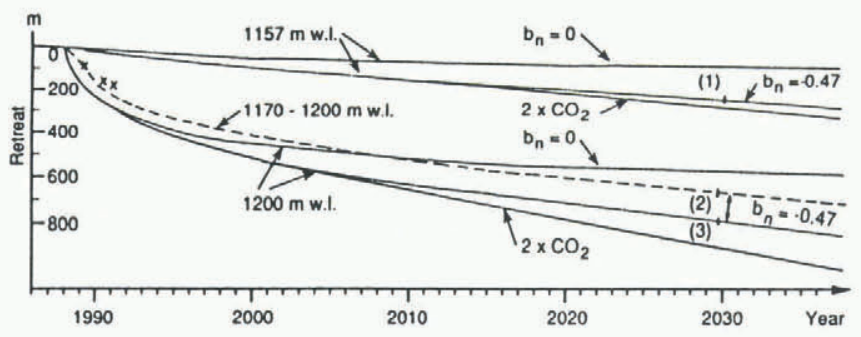

Fig. 8. Predicted glacier-front position versus time for various climate scenarios and water levels. 
climate the retreat seems to be an additional $50 \mathrm{~m}$.

The increase in water level is of great importance. For $\mathrm{b}_{\mathrm{n}}=0$ and $1200 \mathrm{~m}$ a.s.l. water level, the simulation gives $600 \mathrm{~m}$ retreat in 50 years, with $80 \%$ of this during the first ten years. This is in good agreement with the estimate of Hooke and others (1989) based on similar assumptions.

The influence of climate change on the front position is predicted to be less than the influence of increased calving. This is illustrated by the curves for $1200 \mathrm{~m}$ water level, which are identical during the first five years and then diverge. The retreat for $b_{n}=-0.47$ is $900 \mathrm{~m}$, and for $2 \times \mathrm{CO}_{2}$ it is $1000 \mathrm{~m}$ in 50 years.

The broken line in Fig. 8 gives the result of varying water level with $b_{n}=-0.47$. In this case the glacier is predicted to retreat $750 \mathrm{~m}$ in 50 years. This is considered to be the most probable result of water-level regulation.

The water-level changes affect not only the outermost parts of the glacier, but also should be seen further upglacier. The surface should be somewhat lowered due to the increased velocity, and the profile is expected to become steeper as the glacier tries to adapt to the increasing calving rate (Fig. 9).

\section{COMPARISON WITH OBSERVATIONS}

The water level started to rise in June 1988 (Fig. 3). The retreat of the terminus from spring 1988 to spring 1989 averaged $75 \mathrm{~m}$. The velocity near the front during during the same period increased from 25 to $36 \mathrm{~m} \mathrm{a}^{-1}$, which gives a new calving rate of $111 \mathrm{~m} \mathrm{a}^{-1}$.

The water-level rise continued during June and July 1989. This was expected to have a large influence on the calving activity. However, the calving activity during this period was very low. The position of the terminus did not change from spring to autumn 1989. Possibly the low calving rate was due to the cold summer, in which the lake-ice cover did not break up until the middle of August, or possibly the glacier was stuck in deep sediment layers. However, during the flooded conditions in autumn some large pieces started to break off, the largest with an estimated volume of $30000 \mathrm{~m}^{3}$. The total retreat of the terminus from spring 1989 to autumn 1990 was $\sim 100 \mathrm{~m}$.

The measured response of the glacier terminus for the first three years, plotted in Fig. 8 (crosses), is in good agreement with the simulations.

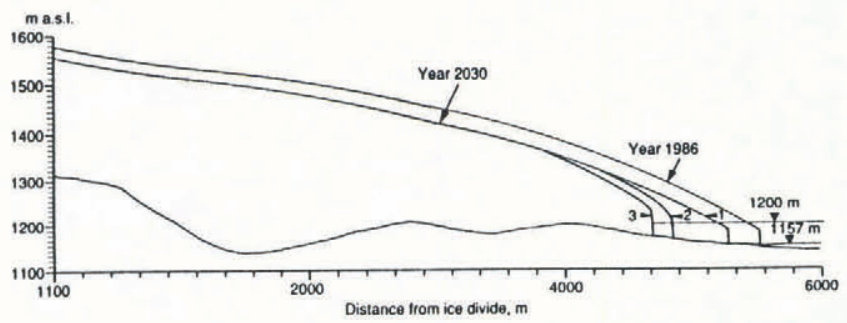

Fig. 9. Longitudinal profile measured in 1986, and simulated for 2030 A.D. with $b_{n}=-0.47$. (1 is water level $1157 \mathrm{~m}$ a.s.l, 2 is expected normal yearly water-level variations, 3 is water level $1200 \mathrm{~m}$ a.s.l.)

\section{ACKNOWLEDGEMENTS}

This work was financed by the Norwegian State Power Board and the Norwegian Water Resources and Energy Administration. Field work was carried out by several staff members of our department, who also helped by other ways. We thank them all, and in particular Mike Kennett and Roger LeB. Hooke for valuable discussions.

\section{REFERENCES}

Bindschadler, R. 1982. A numerical model of temperate glacier flow applied to the quiescent phase of a surgetype glacier. F. Glaciol., 28(99), 239-265.

Bindschadler, R. 1983. The importance of pressurized subglacial water in separation and sliding at the glacier bed. 7. Glaciol., 29(101), 3-19.

Budd, W.F., P. L. Keage and N.A. Blundy. 1979. Empirical studies of ice sliding. 7. Glaciol., 23(89), 157-170.

Eliassen, A. and 6 others. Unpublished. Klimaendringer i Norge ved økt drivhuseffekt. Rapport til Miljøverndepartementets klimautredningsgruppe.

Funk, M. and H. Röthlisberger. 1989. Forecasting the effects of a planned reservoir which will partially flood the tongue of Unteraargletscher in Switzerland. Ann. Glaciol., 13, 76-81.

Hanson, B. H. 1985. Climate sensitivity of a numerical model of ice-sheet dynamics. (Ph.D.thesis, University of Minnesota. National Center for Atmospheric Research. Cooperative Thesis 91.)

Hooke, R. LeB., C. F. Raymond, R. L. Hotchkiss and R.J. Gustafson. 1979. Calculations of velocity and temperature in a polar glacier using the finite-element method. 7. Glaciol., 24(90), 131-146.

Hooke, R. LeB., T. Laumann and M. I. Kennett. 1989. Austdalsbreen, Norway: expected reaction to a $40 \mathrm{~m}$ increase in water level in the lake into which the glacier calves. Cold Reg. Sci. Technol., 17(2), 113-126.

Laumann, T. 1987. En dynamisk modell for isbreers bevegelse. Oslo, Norges Vassdrags- og Energiverk. Vassdragsdirektoratet. Hydrologisk avdeling. (V-publikasjon 8.)

Paterson, W.S.B. 1981. The physics of glaciers. Second edition. Oxford, etc., Pergamon Press.

Sælthun, N.R. and 6 others. 1990. Klimaendringer og vannressurser. Bidrag til den interdepartementale klimautredningen. Oslo, Norges Vassdrags- og Energiverk. Vassdragsdirektoratet. Hydrologisk avdeling. (V-publikasjon 30.)

Sætrang, A. C. 1987. Kartlegging av istykkelse på nordre Jostedalsbreen. Oslo, Norges Vassdrags- og Energiverk. (Oppdragsrapport 8-87.)

Van der Veen, C.J. and I. M. Whillans. 1989a. Force budget: I. Theory and numerical methods. F. Glaciol., 35(119), 53-60.

Van der Veen, G.J. and I. M Whillans. 1989b. Force budget: II. Application to two-dimensional flow along Byrd Station Strain Network, Antarctica. 7. Glaciol., 35(119), 61-67.

The accuracy of references in the text and in this list is the responsibility of the author/s, to whom queries should be addressed. 